\title{
DAMPAK FDI VERTIKAL DAN HORIZONTAL TERHADAP NILAI TAMBAH 18 SUB SEKTOR INDUSTRI MAKANAN DOMESTIK
}

\section{The Effect of Vertical and Horizontal FDI on 18 Sub Sektor Domestic Food Industry Value Added}

\author{
Fitria Yuliani ${ }^{1}$, Hermanto Siregar ${ }^{2}$, Widyastutik ${ }^{2}$, Amzul Rifin $^{3}$ \\ ${ }^{1}$ Direktorat Jenderal Tanaman Pangan, Kementerian Pertanian RI, JI.AUP No.3 \\ Pasar Minggu, Jakarta, Indonesia \\ 2Departemen Ekonomi, ${ }^{3}$ Departemen Ekonomi Sumber Daya Lingkungan, Fakultas Ekonomi dan \\ Manajemen, Institut Pertanian Bogor, Jl.Raya Darmaga, Bogor, Jawa Barat, 16680, Indonesia \\ E-mail: fitria.program@gmail.com
}

Naskah diterima: 08/10/2018; Naskah direvisi: 23/02/2019; Disetujui diterbitkan: 14/05/2019

Dipublikasikan online: 31/12/2019

\begin{abstract}
Abstrak
Untuk meningkatkan pertumbuhan ekonomi, Indonesia membutuhkan investasi asing langsung/Foreign Direct Investment (FDI) karena tingkat tabungan di Indonesia jauh lebih kecil dibandingkan kebutuhan investasi. FDI diyakini dapat meningkatkan nilai tambah suatu sektor atau industri. FDI terdiri dari dua jenis, yaitu FDI horizontal (intra industri) dan FDI vertikal (inter industri - dengan keterkaitan ke depan dan ke belakang). Penelitian ini bertujuan untuk mengetahui dampak FDI vertikal dan horizontal terhadap nilai tambah di 18 sub sektor industri makanan domestik. Dengan menggunakan metode estimasi fixed effect cross section SUR model dan random effect model, hasil penelitian menunjukkan FDI vertikal dengan keterkaitan ke belakang memberikan dampak paling besar terhadap nilai tambah perusahaan domestik dibandingkan FDI vertikal dengan keterkaitan ke depan dan horizontal. FDI vertikal dengan keterkaitan ke belakang berdampak positif terhadap nilai tambah perusahaan domestik dengan modal rendah dan padat tenaga kerja (padat karya). Oleh karena itu, investasi asing di industri makanan paling hilir, seperti industri minuman tidak beralkohol dan industri makanan lainnya perlu dibuka dengan persyaratan bagi investor asing melakukan kerja sama sub contracting dengan perusahaan domestik di industri makanan hulu.
\end{abstract}

Kata kunci: Industri Makanan Domestik, FDI Horizontal, FDI Vertikal, Keterkaitan ke Belakang, Keterkaitan ke Depan, Nilai Tambah

\begin{abstract}
To boost its economic growth, Indonesia needs Foreign Direct Investment (FDI) since the national savings rate is relatively low compared to the high demand for investments. FDI has been proven to be able to enhance the value-added of a sector or industry. There are 2 types of FDI which are Horizontal FDI (intra-industry) and Vertical FDI (inter industry-with upstream and downstream linkages). This study aimed to analyze the impact of horizontal and vertical FDI on the value added to the 18 subsectors in the domestic food industry. By using the fixedeffect cross-section SUR and random effect model, the results showed that the vertical FDI on downstream linkages gives a more positive effect on value-added than vertical FDI on upstream linkages and horizontal FDI. The vertical FDI on downstream linkages gives a positive impact on local companies with a lower level of capital but higher labor (laborintensive). Therefore, FDI on downstream linkages (for example other food industry, nonalcoholic beverages, etc) should be opened on conditions that it commits a sub-contracting cooperation with the domestic firms within the food processing industry in upstream sectors.
\end{abstract}

Keywords: Domestic Food Industry, Downstream Linkages, Horizontal FDI, Vertical FDI, Upstream Linkages, Value Added

JEL Classification: F21; E22; C23; O33 


\section{PENDAHULUAN}

Dalam kerangka ekonomi makro RPJMN 2015-2019, Pemerintah Indonesia memproyeksikan pertumbuhan ekonomi Indonesia rata-rata $7 \%$. Untuk mendukung pertumbuhan ekonomi dibutuhkan peningkatan investasi yang cukup tinggi. Investasi bisa didapatkan melalui tabungan domestik. Namun, tingkat tabungan domestik di Indonesia jauh lebih kecil dibandingkan kebutuhan investasi. Berdasarkan data yang diperoleh dari
Badan Pusat Statistik (BPS), dari tahun 2009 sampai dengan tahun 2017, tingkat tabungan bruto domestik Indonesia lebih rendah dibandingkan tingkat investasi non-finansial domestik Indonesia. Oleh karena itu, untuk menutup perbedaan antara tingkat tabungan dan tingkat investasi nonfinansial domestik Indonesia diperlukan investasi asing. Perbedaan antara tingkat tabungan dan tingkat investasi non-finansial domestik Indonesia tahun 2009-2017 dapat dilihat pada Gambar 1.

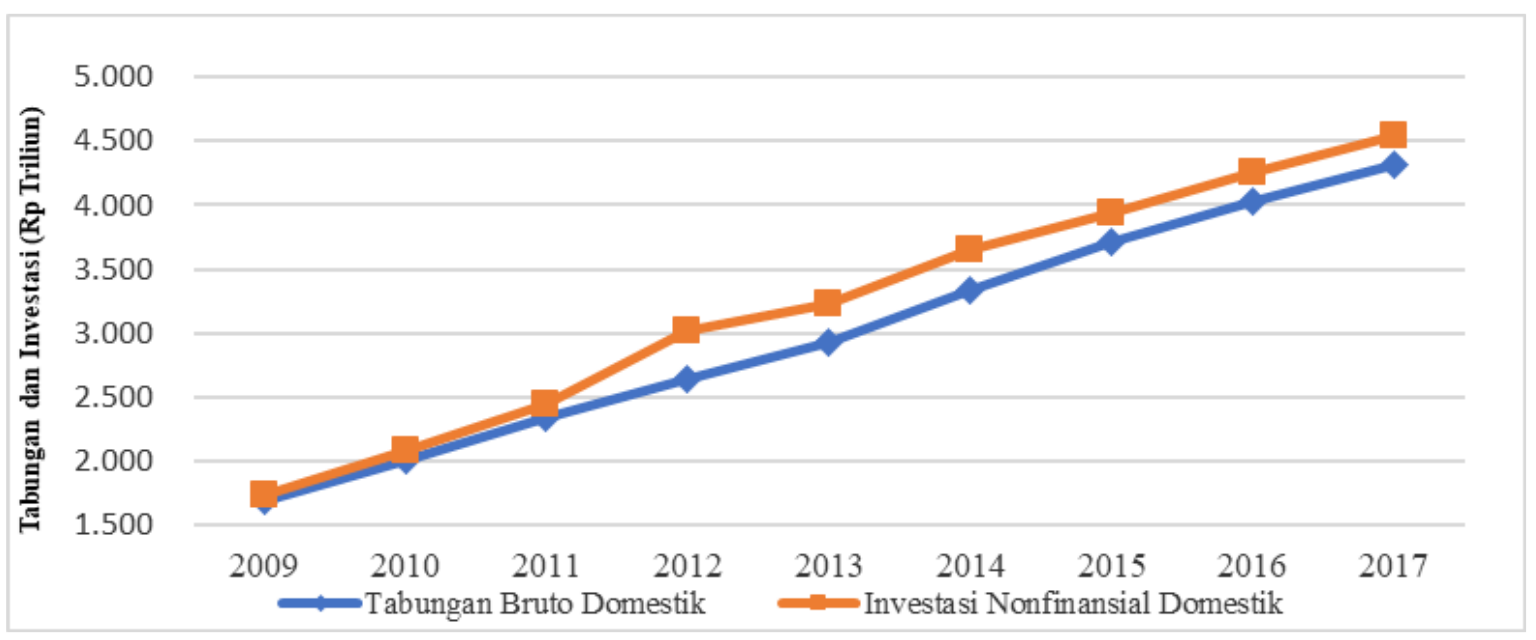

Gambar 1. Perbedaan Tingkat Tabungan Bruto Domestik dan Investasi Non Finansial Domestik Indonesia, Periode 2009-2017

Sumber: Statistik Indonesia, 2018

Investasi asing terdiri dari investasi asing portofolio dan investasi asing langsung. Investasi asing langsung (FDI) adalah investasi yang ditanamkan oleh pemilik modal (individu ataupun kelompok) di negara lain dengan mendirikan perusahaan atau membeli saham perusahaan di negara lain minimal 10\%. Investasi asing tersebut berupa aset riil, seperti tanah, bangunan, peralatan, atau teknologi yang ditanamkan di negara tuan rumah. 
Menurut Krugman (1994), FDI adalah arus modal internasional dimana perusahaan dari suatu negara mendirikan atau memperluas perusahaannya di negara lain.

Ada dua tipe FDI, yaitu FDI horizontal dan FDI vertikal (Beugelsidjk et al, 2008). FDI horizontal bertujuan mendekati pasar, sehingga dapat mengurangi biaya transportasi dan pembatasan perdagangan (Buckley et al, 1981). Sementara FDI vertikal bertujuan mencari faktor-faktor produksi yang lebih efisien.

Pada umumnya, FDI vertikal yang masuk ke dalam negeri merupakan investasi perusahaan asing yang membutuhkan bahan baku dari perusahaan domestik yang lebih banyak menggunakan tenaga kerja tidak terdidik dalam proses produksinya (Braconier, 2005; Markusen, 1995). Upah tenaga kerja tidak terdidik lebih murah di dalam negeri sehingga harga produk yang menjadi bahan baku perusahaan asing menjadi lebih murah. Hal tersebut menyebabkan perusahaan asing tertarik untuk menanamkan modalnya di dalam negeri (FDI).

FDI vertikal memiliki dua saluran utama, yaitu melalui keterkaitan ke depan dan ke belakang. Keterkaitan ke depan adalah keterkaitan bisnis antara perusahaan domestik dengan perusahaan asing, dimana perusahaan domestik mendapatkan bahan bakunya dari perusahaan asing. Sementara keterkaitan ke belakang adalah keterkaitan bisnis antara perusahaan domestik dan perusahaan asing dimana perusahaan domestik memasok atau menyediakan bahan baku untuk perusahaan asing (Javorcik, 2004).

FDI mulai masuk ke Indonesia sejak tahun 1967, yaitu pada saat Undang-Undang No.1 Tahun 1967 tentang Penanaman Modal Asing diterbitkan. Berdasarkan Tabel 1. diketahui bahwa investasi asing langsung (FDI) yang terbesar di Indonesia selama tahun 1990-2017 adalah sektor industri makanan. Kemudian disusul oleh FDI di sektor industri alat angkutan dan transportasi serta tanaman pangan dan perkebunan. FDI di sektor industri makanan merupakan FDI horizontal. Sementara FDI di sektor tanaman pangan dan perkebunan merupakan FDI vertikal dengan keterkaitan ke depan. FDI vertikal dengan keterkaitan ke belakang diwakili oleh FDI di sektor hotel dan restoran yang menempati posisi ke-18. 


\section{Tabel 1. Total Realisasi FDI di Indonesia Berdasarkan Sektor/Sub Sektor, Periode 1990-2017}

\begin{tabular}{clr}
\hline No & \multicolumn{1}{c}{ Sektor/ Sub Sektor } & FDI (US \$ Ribu) \\
\hline 1 & Industri Makanan & $256.689 .270,7$ \\
2 & Industri Alat Angkutan dan Transportasi Lainnya & $157.166 .168,4$ \\
3 & Tanaman Pangan dan Perkebunan & $129.588 .301,0$ \\
4 & Industri Logam Dasar, Barang Logam, Mesin dan Elektronik & $112.106 .954,2$ \\
5 & Industri Mineral Non Logam & $72.559 .297,2$ \\
6 & Transportasi, Gudang dan Telekomunikasi & $70.998 .862,5$ \\
7 & Industri Karet, Barang dari karet dan Plastik & $43.289 .267,1$ \\
8 & Industri Kimia Dasar, Barang Kimia dan Farmasi & $42.086 .250,5$ \\
9 & Pertambangan & $31.074 .044,9$ \\
10 & Listrik, Gas dan Air & $24.877 .730,0$ \\
11 & Peternakan & $24.220 .209,4$ \\
12 & Perumahan, Kawasan Industri dan Perkantoran & $13.141 .177,3$ \\
13 & Industri Kertas, Barang dari kertas dan Percetakan & $11.531 .972,9$ \\
14 & Industri Tekstil & $9.950 .285,5$ \\
15 & Perdagangan dan Reparasi & $9.650 .875,7$ \\
16 & Jasa Lainnya & $9.289 .488,0$ \\
17 & Konstruksi & $8.905 .479,5$ \\
18 & Hotel dan Restoran & $8.764 .534,2$ \\
19 & Industri Lainnya & $4.965 .678,1$ \\
20 & Industri Kulit, Barang dari kulit dan Sepatu & $3.660 .022,9$ \\
21 & Industri Kayu & $2.191 .210,4$ \\
22 & Kehutanan & $489.512,2$ \\
23 & Perikanan & $450.528,7$ \\
24 & Industri Instrumen Kedokteran, Presisi, Optik dan Jam & $238.472,7$ \\
\hline
\end{tabular}

Sumber: BKPM (2017)

Dengan tingginya FDI di industri makanan, baik horizontal (FDI industri makanan) maupun vertikal (FDI sektor tanaman pangan dan perkebunan), seharusnya nilai tambah di industri makanan dapat meningkat pesat. Berdasarkan data laju nilai tambah sub sektor industri tahun 2017, laju nilai tambah industri makanan tidak terlalu besar jika dibandingkan dengan industri lain yang investasi asingnya tidak sebesar industri makanan (industri tekstil, industri non logam, dan industri alat angkut (Gambar 2). 


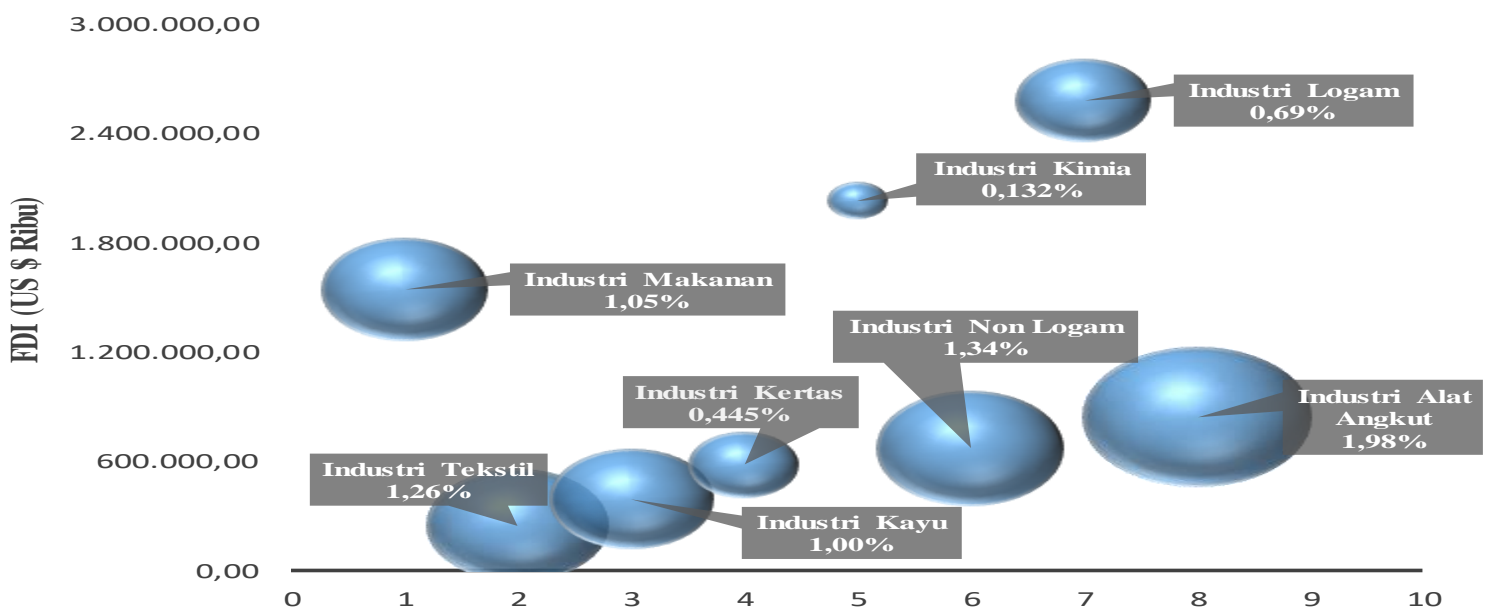

Gambar 2. FDI dan Laju Nilai Tambah Industri Makanan Dibandingkan dengan Sektor Industri Lainnya di Indonesia, Tahun 2017

Sumber: Statistik Indonesia (2018)

Rendahnya laju nilai tambah di

industri makanan hewan, industri industri makanan diperkirakan minuman tidak beralkohol, dan industri disebabkan oleh beragamnya sub sektor di industri makanan. Berdasarkan KBLI 2015, beberapa sub sektor di industri makanan diantaranya adalah industri pemotongan hewan, industri pengolahan dan pengawetan daging, industri pengolahan dan pengawetan ikan, industri pengolahan dan pengawetan buah-buahan dan sayuran, industri minyak nabati dan hewani, industri minyak kelapa, industri minyak kelapa sawit, industri penggilingan padi, penyosohan beras, dan tepung beras, industri penggilingan serealia lainnya dan tepung terigu, industri roti dan kue, industri mie dan makaroni, industri susu, industri gula, industri coklat dan kembang gula, industri kopi dan teh, makanan lainnya.

Masing-masing sub sektor tersebut memiliki FDI horizontal dan vertikal (dengan keterkaitan ke depan dan ke belakang) yang berbeda-beda. Dampak FDI horizontal dan vertikal (dengan keterkaitan ke depan serta ke belakang) terhadap nilai tambah di masing-masing sub sektor industri makanan tersebut pun diperkirakan berbeda-beda, ada yang berdampak positif, negatif, atau bahkan tidak memberikan dampak apapun. Hal tersebut mengakibatkan nilai tambah di industri makanan tidak optimal. Untuk mengoptimalkan dampak FDI vertikal dan horizontal terhadap nilai tambah di industri makanan, perlu diketahui FDI di 
sub sektor mana saja yang dapat memberikan dampak positif ataupun negatif.

Beberapa penelitian mengenai dampak FDI yang telah dilakukan di Indonesia diantaranya adalah Sjoholm (1998) dan Sari (2016). Sjoholm (1998) menyatakan bahwa FDI horizontal berdampak positif terhadap perusahaan-perusahaan di tingkat nasional. Sementara, di tingkat provinsi, FDI horizontal tidak signifikan memengaruhi perusahaan dan berdampak negatif terhadap perusahaan di tingkat kabupaten/kota. Selain itu, FDI vertikal berdampak positif terhadap produktivitas perusahaan di tingkat provinsi maupun kabupaten/kota. Sjoholm (1998) juga menyatakan bahwa FDI horizontal di sektor industri makanan berdampak negatif terhadap perusahaan. Sementara FDI vertikal di sektor industri makanan berdampak positif terhadap produktivitas perusahaan.

Sari (2016) menunjukkan bahwa spillover horizontal dan spillover vertikal dengan keterkaitan ke depan berdampak negatif terhadap produktivitas perusahaan-perusahaan di semua sektor industri. Sementara spillover vertikal dengan keterkaitan ke belakang berdampak positif terhadap produktivitas perusahaan-perusahaan di semua sektor industri. Sari (2016) juga menyatakan bahwa perusahaan dengan tingkat kepemilikan saham asing yang lebih tinggi mendapatkan dampak spillover positif yang lebih besar. Berdasarkan beberapa hasil penelitian tersebut belum dapat diketahui dampak dari spillover FDI terhadap nilai tambah dan produktivitas perusahaan di sub sektor industri makanan. Oleh karena itu, penelitian ini akan menganalisis dampak FDI vertikal dan horizontal terhadap nilai tambah perusahaan domestik di 18 sub sektor industri makanan.

\section{METODE}

Berdasarkan teori pertumbuhan baru, FDI merupakan mesin penggerak pertumbuhan ekonomi suatu negara karena dapat memberikan eksternalitas melalui transfer teknologi. Menurut teori pertumbuhan baru, kemajuan teknologi sangat penting dalam pertumbuhan output. Oleh karena itu, FDI sangat penting dalam pertumbuhan output/nilai tambah.

Oleh karena kemajuan teknologi sangat penting dalam pertumbuhan output, Solow memodifikasi model pertumbuhannya dari fungsi produksi neoklasik dengan memasukkan input lain yaitu knowledge atau kemajuan 
teknologi (technical progress) ke dalam model melalui efektifitas tenaga kerja (effectiveness of labor). Fungsi produksi Solow mengikuti bentuk :

$Y=f(K, A L)$

Variabel $A L$ adalah effective labor, dimana pengaruh kemajuan teknologi masuk ke dalam sistem melalui bentuk tersebut. Bentuk ini dikenal dengan istilah labor augmenting atau harrod neutral. Jika teknologi masuk melalui bentuk $Y=f(A K, L)$ dinamakan capital augmenting. Sementara jika teknologi masuk melalui bentuk $Y=A f(K, L)$ dinamakan hicks-neutral.

FDI yang membawa kemajuan teknologi terdiri dari FDI horizontal dan FDI vertikal. FDI horizontal adalah investasi perusahaan asing yang beroperasi di dalam industri yang sama dengan perusahaan domestik, di mana perusahaan domestik mendapatkan manfaat dari FDI tersebut. Sementara FDI vertikal adalah investasi perusahaan asing dimana perusahaan domestik di sektor lain yang berhubungan dalam bisnis dengan perusahaan asing mendapatkan manfaat dari FDI tersebut.

FDI vertikal dapat terjadi melalui keterkaitan ke belakang dan keterkaitan ke depan. Melalui keterkaitan ke depan, perusahaan asing di sektor pemasok input antara akan memberikan input antara yang lebih baik. Input antara yang lebih baik tersebut diharapkan akan meningkatkan nilai tambah industri hilir dalam negeri. Melalui keterkaitan ke belakang, perusahaan asing memiliki insentif untuk alih teknologi kepada pemasok input antara, yang diharapkan dapat meningkatkan nilai tambah industri hulu dalam negeri. Pada umumnya, kontrak antara pemasok input antara domestik dengan perusahaan asing memaksakan pemasok input antara dengan persyaratan kualitas produk dan manajemen atau teknologi yang lebih tinggi. Perusahaan asing akan melakukan alih teknologi langsung dari afiliasi asing ke pemasok domestik sehingga pemasok domestik mendapatkan keuntungan dari skala ekonomi (Javorcik, 2004).

Pengukuran FDI vertikal dengan keterkaitan ke depan dan ke belakang menggunakan proporsi output yang digunakan oleh industri lain dengan keterkaitan ke depan dan ke belakang dikalikan dengan investasi perusahaan asing dengan keterkaitan ke depan dan ke belakang dalam industri (Liu, 2008). Proporsi output yang digunakan oleh industri lain dengan keterkaitan ke depan dan ke belakang didasarkan atas Tabel Input Output. 
Menurut Crespo \& Fontoura (2007), faktor-faktor yang memengaruhi dampak FDI adalah kapasitas penyerapan. Kapasitas penyerapan adalah kemampuan untuk menginternalisasi pengetahuan yang diciptakan oleh orang lain dan memodifikasinya agar sesuai dengan aplikasi spesifik yang dibutuhkannya. Kapasitas penyerapan dapat dilihat dari jumlah sumber daya manusianya. Selain itu, perusahaan asing juga menggunakan teknologi tinggi, sehingga untuk melakukan imitasi, perusahaan domestik juga membutuhkan kapasitas penyerapan melalui modal yang dimilikinya.

Terkait dengan hal tersebut diatas, penelitian ini relevan untuk menganalisis dampak FDI vertikal dan horizontal terhadap nilai tambah perusahaan domestik. Dampak FDI horizontal yang dianalisis merupakan dampak FDI horizontal yang terjadi melalui imitasi perusahaan domestik yang dipengaruhi oleh faktor kapasitas penyerapan (modal dan tenaga kerja). Sementara dampak FDI vertikal yang dianalisis merupakan FDI vertikal yang terjadi melalui keterkaitan produksi atau kerja sama sub contracting antara perusahaan-perusahaan asing dengan perusahaan-perusahaan domestik yang juga dipengaruhi oleh faktor kapasitas penyerapan (modal dan tenaga kerja).

\section{Model Estimasi dan Metode Analisis}

Model penelitian mengadopsi model Liang (2016). Variabel dependen yang digunakan adalah nilai tambah. Berbeda dengan output, nilai tambah adalah selisih nilai produk dengan nilai biaya bahan baku dan input lainnya, tidak termasuk tenaga kerja (Slamet, 2005). Nilai tambah merupakan penerimaan upah kerja ditambah dengan keuntungan pemilik modal atau nilai produk dikurangi dengan pengeluaran bahan baku dan bahan tambahan lainnya (Maharani, 2013).

Variabel independen yang digunakan adalah modal, tenaga kerja, dan FDI (horizontal serta vertikal dengan keterkaitan ke depan dan kebelakang). Hal tersebut disebabkan karena Liang (2016) mengadopsi model Solow yang menggunakan dua input dalam proses produksinya, yaitu modal dan tenaga kerja. Solow juga memasukkan kemajuan teknologi sebagai faktor lain yang memengaruhi output. Oleh karena itu, modal, tenaga kerja, dan FDI (sebagai pembawa kemajuan teknologi) digunakan sebagai variabel independen karena merupakan faktor-faktor yang memengaruhi nilai tambah. 
Di dalam model tersebut juga ditambahkan variabel interaksi antara FDI (horizontal maupun vertikal dengan keterkaitan ke depan dan ke belakang) dengan kapital dan tenaga kerja. Penambahan variabel interaksi tersebut merujuk pada model Solow yang dimodifikasi berupa labor augmenting dan capital augmenting.

Modal dan tenaga kerja digunakan dalam interaksi karena merupakan karakteristik perusahaan yang menunjukkan kapasitas penyerapan perusahaan untuk memperoleh dampak FDI. Interaksi tersebut bertujuan untuk melihat dampak FDI terhadap nilai tambah perusahaan domestik melalui kapasitas penyerapannya. Model estimasi yang digunakan yaitu:

$\ln Y_{i j t}=\alpha+\beta_{1} \ln K_{i j t}+\beta_{2} \ln L_{i j t}+\beta_{3} U F_{j t}+\beta_{4}$ $H F_{j t}+\beta_{5} D F_{j t}+\beta_{6} \operatorname{lnK}_{i j t}{ }^{*} U F_{j t}+\beta_{7} \ln K_{i j t}{ }^{*}$

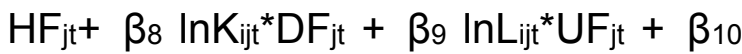
$\ln L_{i j t}{ }^{*} H F_{j t}+\beta_{11} \ln L_{i j t}{ }^{*} D F_{j t}+\varepsilon i t$

Keterangan:

$Y_{i j t}$ : Nilai tambah perusahaan i di industri j pada tahun ke $\mathrm{t}$ (Ribu Rupiah)

$\mathrm{K}_{\mathrm{ijt}}$ : Nilai aset tetap perusahaan $\mathrm{i}$ di industri j pada tahun ke $\mathrm{t}$ (Ribu Rupiah)

$\mathrm{L}_{\mathrm{ijt}}$ : Jumlah tenaga kerja produksi pada perusahaan i di industri j pada tahun ke $\mathrm{t}$ (Orang)
UF $_{\mathrm{jt}}$ : Investasi asing langsung (FDI) vertikal dengan keterkaitan ke depan di industri j pada tahun ke $\mathrm{t}(\%)$

$\mathrm{HF}_{\mathrm{jt}}$ : Investasi asing langsung (FDI) horizontal di industri j pada tahun ke $\mathrm{t}(\%)$

$\mathrm{DF}_{\mathrm{jt}}$ : Investasi asing langsung (FDI) vertikal dengan keterkaitan ke belakang di industri j pada tahun ke $\mathrm{t}(\%)$

$\varepsilon_{\text {it }}$ : Residual persamaan regresi (error term)

$\beta_{1}, \beta_{2}, \beta_{3}, \beta_{4}, \beta_{5}, \beta_{6}, \beta_{7}, \beta_{8}, \beta_{9}, \beta_{10}, \beta_{11}$ : Koefisien dari variabel independen

Untuk menentukan model data panel terbaik yang akan digunakan, perlu dilakukan beberapa pengujian statistik, yaitu uji Chow dan uji Hausman. Uji Chow dilakukan untuk mengetahui apakah data yang diobservasi memiliki kesamaan perilaku antar waktu dan antar sektor. Jika data memiliki kesamaan perilaku antar waktu dan antar sektor, maka digunakan model Pooled Least Square. Sementara jika data tidak terdapat kesamaan perilaku antar waktu dan antar sektor, maka digunakan model Fixed Effect.

Apabila hasil uji menunjukkan bahwa model yang sebaiknya digunakan adalah Fixed Effect, maka dilanjutkan dengan uji Hausman. Uji 
Hausman dilakukan untuk melihat apakah terdapat korelasi antara unobserved heterogeneity dengan variabel independen. Jika terdapat korelasi antara unobserved heterogeneity dengan variabel independen, maka digunakan model Fixed Effect. Namun, jika tidak terdapat korelasi, digunakan model Random Effect. Apabila hasil pemilihan model dengan menggunakan uji Chow dan uji Hausman mendapatkan hasil bahwa model yang terbaik adalah Fixed Effect Model, maka perlu dilakukan beberapa pengujian statistik lagi, yaitu uji LM dan uji LR.

Uji LM (Lagrange Multiplier test) dilakukan untuk mengetahui apakah varians error bersifat homoskedastis atau heteroskedastis. Jika hasil estimasi menunjukkan bahwa varians error bersifat heteroskedastis, maka untuk mengestimasi model ini harus digunakan metode fixed effect cross section weight. Selanjutnya, dilakukan uji LR (Likelihood Ratio test) untuk mengetahui apakah struktur heteroskedastis dan autokorelasi disebabkan oleh antar unit atau antar unit dan antar waktu. Jika struktur heteroskedastis dan autokorelasi disebabkan oleh antar unit, maka metode fixed effect cross section weight cocok digunakan dalam estimasi ini. Sementara jika struktur heteroskedastis dan autokorelasi disebabkan oleh antar unit dan antar waktu, maka untuk mengestimasi model ini harus digunakan metode fixed effect cross section SUR.

Sektor industri makanan yang memiliki jumlah perusahaan domestik lebih kecil dibandingkan lamanya waktu observasi (25 tahun) akan diestimasi dengan fixed effect cross section SUR model. Hal itu karena diperkirakan terjadi unobserved heterogeneity antar sektor atau dengan kata lain masingmasing sektor diyakini memiliki karakteristik yang berbeda-beda dan karakteristik tersebut memiliki korelasi dengan variabel independen yang ada di dalam model. Selain itu, dalam model juga diasumsikan akan terjadi heteroskedastisitas dan autokorelasi yang disebabkan antar sektor dan antar waktu. Sementara pada sektor industri makanan yang memiliki jumlah perusahaan domestik lebih besar dibandingkan lamanya waktu observasi (25 tahun) akan diestimasi dengan random effect model. Hal tersebut disebabkan karena jumlah perusahaan terlalu banyak sehingga jika diestimasi dengan menggunakan fixed effect cross section SUR model akan mengurangi 
derajat bebas dan mengurangi efisiensi parameter yang diestimasi.

Berdasarkan model yang digunakan, dampak FDI vertikal dengan keterkaitan ke depan (upstream linkage) dan interaksinya dengan kapasitas penyerapan (modal dan tenaga kerja) terhadap nilai tambah perusahaan domestik adalah sebagai berikut:

$$
\begin{array}{r}
\frac{\partial \ln Y_{i j t}}{\partial U F_{j t}}=\beta_{3}+\beta_{6} * \ln K_{i j t}+\beta_{9} * \ln L_{i j t} \\
\beta_{3}, \beta_{6}, \beta_{9}>0
\end{array}
$$

Dampak FDI horizontal dan interaksinya dengan kapasitas penyerapan (modal dan tenaga kerja) terhadap nilai tambah perusahaan domestik adalah sebagai berikut:

$$
\begin{array}{r}
\frac{\partial \ln Y_{i j t}}{\partial H F_{j t}}=\beta_{4}+\beta_{7} * \ln K_{i j t}+\beta_{10} * \ln L_{i j t} \\
\beta_{4}, \beta_{7}, \beta_{10}>0
\end{array}
$$

Dampak FDI vertikal dengan keterkaitan ke belakang (downstream linkage) dan interaksinya dengan kapasitas penyerapan (modal dan tenaga kerja) terhadap nilai tambah perusahaan domestik adalah sebagai berikut:

$$
\begin{array}{r}
\frac{\partial \ln Y_{i j t}}{\partial D F_{j t}}=\beta_{5}+\beta_{8} * \ln K_{i j t}+\beta_{11} * \ln L_{i j t} \\
\beta_{5}, \beta_{8}, \beta_{11}>0
\end{array}
$$

\section{Jenis dan Sumber Data}

Penelitian ini menggunakan data panel dari 18 sub sektor industri makanan selama kurun waktu 19902014. Pemilihan industri yang digunakan berdasarkan KBLI, yang telah disesuaikan dengan KLUI 1990, KBLI 1997, KBLI 2000, KBLI 2005, KBLI 2009, KBLI 2015, serta kode industri pada Tabel IO Tahun 1990-2010.

Untuk mengkaji dampak FDI horizontal, penelitian ini melihat dampak FDI di masing-masing sub sektor industri makanan terhadap nilai tambahnya. Sementara untuk mengkaji dampak FDI vertikal dengan keterkaitan ke depan (upstream linkage), penelitian ini membatasi dampak dari sektor pertanian atau sub sektor industri makanan yang lain yang berhubungan langsung dengan sub sektor industri makanan tersebut. Sementara, untuk mengkaji dampak FDI vertikal dengan keterkaitan ke belakang (downstream linkage), penelitian ini membatasi dampak dari sub sektor industri makanan yang lain atau sektor pertanian atau sektor penyediaan makanan yang berhubungan langsung dengan sub sektor industri makanan tersebut. Pemilihan sub sektor dengan keterkaitan ke depan ke belakang berdasarkan proporsi penggunaan input/output terbesar pada sub sektor lainnya dengan menggunakan Tabel Input Output (Tabel 2). 


\section{Tabel 2. Sub Sektor Industri Makanan dengan Keterkaitan ke Depan dan ke}

Belakang dalam Penelitian

\begin{tabular}{|c|c|c|}
\hline Upstream Linkage & Sub Sektor Industri Makanan & Downstream Linkage \\
\hline Peternakan & Industri pemotongan hewan & $\begin{array}{l}\text { Industri pengolahan dan } \\
\text { pengawetan daging }\end{array}$ \\
\hline Industri pemotongan hewan & $\begin{array}{l}\text { Industri pengolahan dan } \\
\text { pengawetan daging }\end{array}$ & Industri makanan hewan \\
\hline Perikanan & $\begin{array}{c}\text { Industri pengolahan dan } \\
\text { pengawetan untuk ikan dan biota } \\
\text { perairan lainnya }\end{array}$ & Industri makanan lainnya \\
\hline Buah-Buahan dan Sayuran & $\begin{array}{l}\text { Industri pengolahan dan } \\
\text { pengawetan untuk buah-buahan } \\
\text { dan sayuran }\end{array}$ & $\begin{array}{l}\text { Industri minuman tidak } \\
\text { beralkohol }\end{array}$ \\
\hline $\begin{array}{c}\text { Kacang-Kacangan dan Biji-Bijian } \\
\text { Penghasil Minyak }\end{array}$ & Industri minyak nabati dan hewani & Industri makanan lainnya \\
\hline $\begin{array}{l}\text { Perkebunan Tanaman Penghasil } \\
\text { Minyak }\end{array}$ & Industri minyak kelapa & Industri makanan lainnya \\
\hline $\begin{array}{c}\text { Perkebunan Tanaman Penghasil } \\
\text { Minyak }\end{array}$ & Industri minyak kelapa sawit & Industri makanan lainnya \\
\hline Pertanian Padi & $\begin{array}{l}\text { Industri penggilingan padi, } \\
\text { penyosohan beras, dan tepung } \\
\text { beras }\end{array}$ & Industri makanan lainnya \\
\hline Pertanian Serealia Lainnya & $\begin{array}{l}\text { Industri penggilingan serealia } \\
\text { lainnya dan tepung terigu }\end{array}$ & $\begin{array}{l}\text { Industri Produk Roti dan } \\
\text { Kue serta Industri } \\
\text { Makaroni dan Mie }\end{array}$ \\
\hline $\begin{array}{l}\text { Industri penggilingan serealia lainnya } \\
\text { dan tepung terigu }\end{array}$ & Industri Produk Roti dan Kue & Penyediaan Makanan \\
\hline $\begin{array}{l}\text { Industri penggilingan serealia lainnya } \\
\text { dan tepung terigu }\end{array}$ & Industri Makaroni dan Mie & Penyediaan Makanan \\
\hline Peternakan & Industri makanan dari susu & $\begin{array}{l}\text { Industri makanan dari } \\
\text { coklat dan kembang gula }\end{array}$ \\
\hline Perkebunan Tebu & Industri gula & $\begin{array}{l}\text { Industri minuman tidak } \\
\text { beralkohol }\end{array}$ \\
\hline $\begin{array}{c}\text { Perkebunan Tanaman untuk Bahan } \\
\text { Minuman }\end{array}$ & $\begin{array}{c}\text { Industri makanan dari coklat dan } \\
\text { kembang gula }\end{array}$ & Industri makanan lainnya \\
\hline $\begin{array}{c}\text { Perkebunan Tanaman untuk Bahan } \\
\text { Minuman }\end{array}$ & Industri pengolahan kopi dan teh & $\begin{array}{l}\text { Industri minuman tidak } \\
\text { beralkohol }\end{array}$ \\
\hline $\begin{array}{l}\text { Pertanian Padi dan Serealia } \\
\text { Lainnya,serta Industri pengolahan dan } \\
\text { pengawetan daging }\end{array}$ & Industri makanan hewan & Peternakan \\
\hline Industri gula & Industri minuman tidak beralkohol & Penyediaan Makanan \\
\hline $\begin{array}{l}\text { Industri pengolahan dan pengawetan } \\
\text { untuk ikan, Industri penggilingan padi, } \\
\text { penyosohan beras, dan tepung beras, } \\
\text { Industri minyak, dan Industri makanan } \\
\text { dari coklat }\end{array}$ & Industri makanan lainnya & Penyediaan Makanan \\
\hline
\end{tabular}


Variabel yang digunakan dalam model menggunakan data sekunder yang bersumber dari hasil kuesioner statistik Industri Besar Sedang (IBS) yang tidak dipublikasikan oleh BPS dan data yang dipublikasikan oleh Badan Koordinasi Penanaman Modal (BKPM).

\section{HASIL DAN PEMBAHASAN}

Hasil estimasi dampak FDI vertikal dan horizontal terhadap nilai tambah di industri makanan domestik secara umum, dengan menggunakan fixed effect cross section SUR dapat dilihat pada Tabel 3.

Tabel 3. Dampak Spillover FDI terhadap Nilai Tambah Industri Makanan Domestik dengan Model Fixed Effect Cross Section SUR

\begin{tabular}{|c|c|c|}
\hline \multirow{2}{*}{ Variabel Independen } & \multicolumn{2}{|c|}{ Variabel Dependen } \\
\hline & $\ln Y$ & (t-stat) \\
\hline Konstan & 2,780442 & $(31,55199) * * *$ \\
\hline $\ln K$ & 0,404094 & $(82,03646) * * *$ \\
\hline $\ln \mathrm{L}$ & 0,951489 & $(101,4651) * * *$ \\
\hline UF & 0,053012 & $(28,57423) * * *$ \\
\hline $\mathrm{HF}$ & 0,026389 & $(22,71326) * * *$ \\
\hline $\mathrm{DF}$ & 0,12235 & $(27,30912) * * *$ \\
\hline $\ln \mathrm{K}^{*} \mathrm{UF}$ & $-0,003174$ & $(-29,20015) * * *$ \\
\hline $\ln \mathrm{K} * \mathrm{HF}$ & $-0,001061$ & $(-17,35141) * * *$ \\
\hline $\ln \mathrm{K}^{*} \mathrm{DF}$ & $-0,003667$ & $(-20,05055) * * *$ \\
\hline $\operatorname{lnL} * U F$ & 0,002127 & $(17,06912) * * *$ \\
\hline $\ln \mathrm{L} * \mathrm{HF}$ & 0,00000698 & $(0,083599)$ \\
\hline $\operatorname{lnL} * \mathrm{DF}$ & $-0,003475$ & $(-12,29296) * * *$ \\
\hline R-Squared & \multicolumn{2}{|c|}{0,949431} \\
\hline Adj R-Squared & \multicolumn{2}{|c|}{0,949255} \\
\hline
\end{tabular}

Sumber: Data diolah (2018)

Berdasarkan hasil estimasi diketahui bahwa nilai $R$-squared cukup baik, yaitu sebesar 0,949431. Hal tersebut menunjukkan model yang digunakan baik. Variabel-variabel independen dapat menjelaskan variabel dependennya sebesar $94,94 \%$.

Dampak modal terhadap nilai tambah industri makanan domestik adalah $\left(0,4-0,0032 * \mathrm{UF}_{\mathrm{jt}}-0,0011^{*} \mathrm{HF}_{\mathrm{jt}}\right.$ - 0,0037*DF $\left.{ }^{*} \mathrm{t}\right) \%$. Dengan memasukkan

data rata-rata FDI ke dalam persamaan tersebut, dapat diketahui bahwa peningkatan modal sebesar $1 \%$ akan menurunkan nilai tambah industri makanan domestik sebesar $2,17 \%$. Hal tersebut bertentangan dengan teori Harrod-Domar (1946) dalam Romer (2006) yang menyatakan bahwa pertumbuhan output akan proporsional dengan pertumbuhan modal. Dampak negatif tersebut diduga disebabkan oleh 
modal yang hanya digunakan untuk membeli mesin dan peralatan yang tidak dapat meningkatkan nilai tambah (teknologi rendah). Morrison (1997) menyatakan bahwa modal yang dapat meningkatkan produktivitas di industri pengolahan makanan adalah modal berupa kapital dengan teknologi tinggi. Hasil penelitian Fatkhurahman (2017) juga menyatakan bahwa modal tidak berdampak terhadap nilai produksi industri di Kota Pekanbaru.

Sementara dampak tenaga kerja terhadap nilai tambah industri makanan domestik adalah $\left(0,95+0,002 * \mathrm{UF}_{\mathrm{jt}}-\right.$ $\left.0,003475^{*} \mathrm{DF}_{\mathrm{jt}}\right) \%$. Dengan memasukkan data rata-rata FDI ke dalam persamaan tersebut, dapat diketahui bahwa peningkatan tenaga kerja sebesar $1 \%$ akan meningkatkan nilai tambah industri makanan domestik sebesar $0,77 \%$. Hal tersebut sesuai teori pertumbuhan ekonomi SolowSwan dalam Romer (2006) yang menyatakan bahwa tingkat output dipengaruhi oleh nilai modal dan tenaga kerja.

Hasil estimasi juga menunjukkan bahwa dampak FDI vertikal dengan keterkaitan ke depan terhadap nilai tambah industri makanan adalah $(0,053$ - 0,0032*InK $\left.{ }^{j t}+0,002^{*} \operatorname{InL} \mathrm{jt}\right), \quad$ dampak FDI horizontal adalah $(0,026$ -
0,0011* $\ln K_{\mathrm{jt}}$ ), dan dampak FDI vertikal dengan keterkaitan ke belakang adalah $\left(0,012235 \quad-\quad 0,0037^{*} \operatorname{lnK}_{j t} \quad-\right.$ $\left.0,003475^{\star} \mid n L_{j t}\right)$. Hal tersebut menunjukkan bahwa FDI secara langsung berdampak positif terhadap nilai tambah. Sementara dampaknya melalui modal bernilai negatif. Hanya dampak FDI vertikal dengan keterkaitan ke depan melalui tenaga kerja yang berdampak positif terhadap nilai tambah.

Setelah data dimasukkan ke dalam persamaan-persamaan tersebut, diketahui bahwa FDI (horizontal maupun vertikal dengan keterkaitan ke depan dan ke belakang) berdampak negatif terhadap nilai tambah industri makanan domestik. Peningkatan FDI vertikal dengan keterkaitan ke depan sebesar $1 \%$ akan menurunkan nilai tambah sebesar $0,0026 \%$. Peningkatan FDI horizontal sebesar $1 \%$ akan menurunkan nilai tambah sebesar 0,0017\%. Peningkatan FDI vertikal dengan keterkaitan ke belakang sebesar $1 \%$ akan menurunkan nilai tambah sebesar 0,01825\%. Hal tersebut bertentangan dengan Sjoholm (2016) yang menyatakan bahwa perusahaan asing memberikan dampak positif terhadap nilai tambah perusahaan domestik. Namun, Liang (2016) 
menyatakan bahwa FDI berdampak negatif terhadap perusahaan di industri yang sama (FDI horizontal) maupun terhadap perusahaan domestik penyedia bahan baku (keterkaitan ke belakang). Kokko dan Thang (2014) juga menyatakan bahwa FDI horizontal dan FDI vertikal dengan keterkaitan ke depan berdampak negatif terhadap kemampuan perusahaan domestik untuk bertahan.

Hal ini diduga disebabkan oleh modal yang cukup tinggi di industri makanan domestik namun tidak dapat meningkatkan nilai tambahnya. Modal yang dimiliki oleh industri makanan domestik tidak digunakan untuk meningkatkan penelitian dan pengembangan produk serta kualitas tenaga kerja (capacity building). Modal hanya digunakan untuk pembelian mesin dan peralatan yang tidak dapat meningkatkan nilai tambah. Selain itu, hal tersebut diduga disebabkan oleh penggunaan data per sektor industri yang merupakan akumulasi dari perusahaan-perusahaan sehingga tidak mencerminkan keadaan sebenarnya. Oleh karena itu, maka dilakukan estimasi dengan menggunakan data perusahaan di masing-masing sub sektor industri makanan.
Hasil estimasi dampak FDI terhadap nilai tambah di sektor industri makanan di setiap sub sektor memiliki dampak yang berbeda-beda. Estimasi dilakukan terhadap masing-masing sub sektor industri makanan dengan menggunakan model fixed effect cross section SUR dan random effect. Hal itu dapat dilihat pada Tabel 4.

Berdasarkan Tabel 4 dapat diketahui bahwa FDI vertikal dengan keterkaitan ke depan lebih banyak berdampak positif terhadap nilai tambah perusahaan domestik di industri makanan. Hasil penelitian tersebut sesuai dengan penelitian Liang (2016) yang menyatakan bahwa FDI berdampak positif terhadap produktivitas perusahaan yang menggunakan bahan baku yang berasal dari perusahaan asing. Kee (2014) juga menyatakan bahwa kehadiran perusahaan asing sebagai pemasok input akan meningkatkan cakupan produk, penjualan per pekerja, output per pekerja, dan produktivitas perusahaan domestik.

Peningkatan FDI di sub sektor peternakan sebesar $1 \%$ akan meningkatkan nilai tambah perusahaan domestik pemotongan hewan sebesar 0,0107\%. Peningkatan FDI di sub sektor industri pemotongan hewan sebesar $1 \%$ 
akan meningkatkan nilai tambah perkebunan kelapa sebesar $1 \%$ akan perusahaan domestik pengolahan dan meningkatkan perusahaan domestik pengawetan daging sebesar 0,0538\%. minyak kelapa sebesar 0,0141\%. Peningkatan FDI di sub sektor Peningkatan FDI di sub sektor perikanan sebesar $1 \%$ akan perkebunan kelapa sawit sebesar $1 \%$ meningkatkan nilai tambah perusahaan akan meningkatkan nilai tambah domestik pengolahan dan pengawetan perusahaan domestik minyak kelapa ikan sebesar 0,0061\%. Peningkatan FDI sawit sebesar 0,0413\%. Peningkatan di sub sektor pertanian kacang- FDI di sub sektor pertanian padi sebesar kacangan penghasil minyak sebesar $1 \% \quad 1 \%$ akan meningkatkan nilai tambah akan meningkatkan nilai tambah perusahaan domestik penggilingan perusahaan domestik minyak nabati padi, penyosohan beras, dan tepung dan hewani sebesar 0,0549\%. beras sebesar 0,0099\%.

Peningkatan FDI di sub sektor 


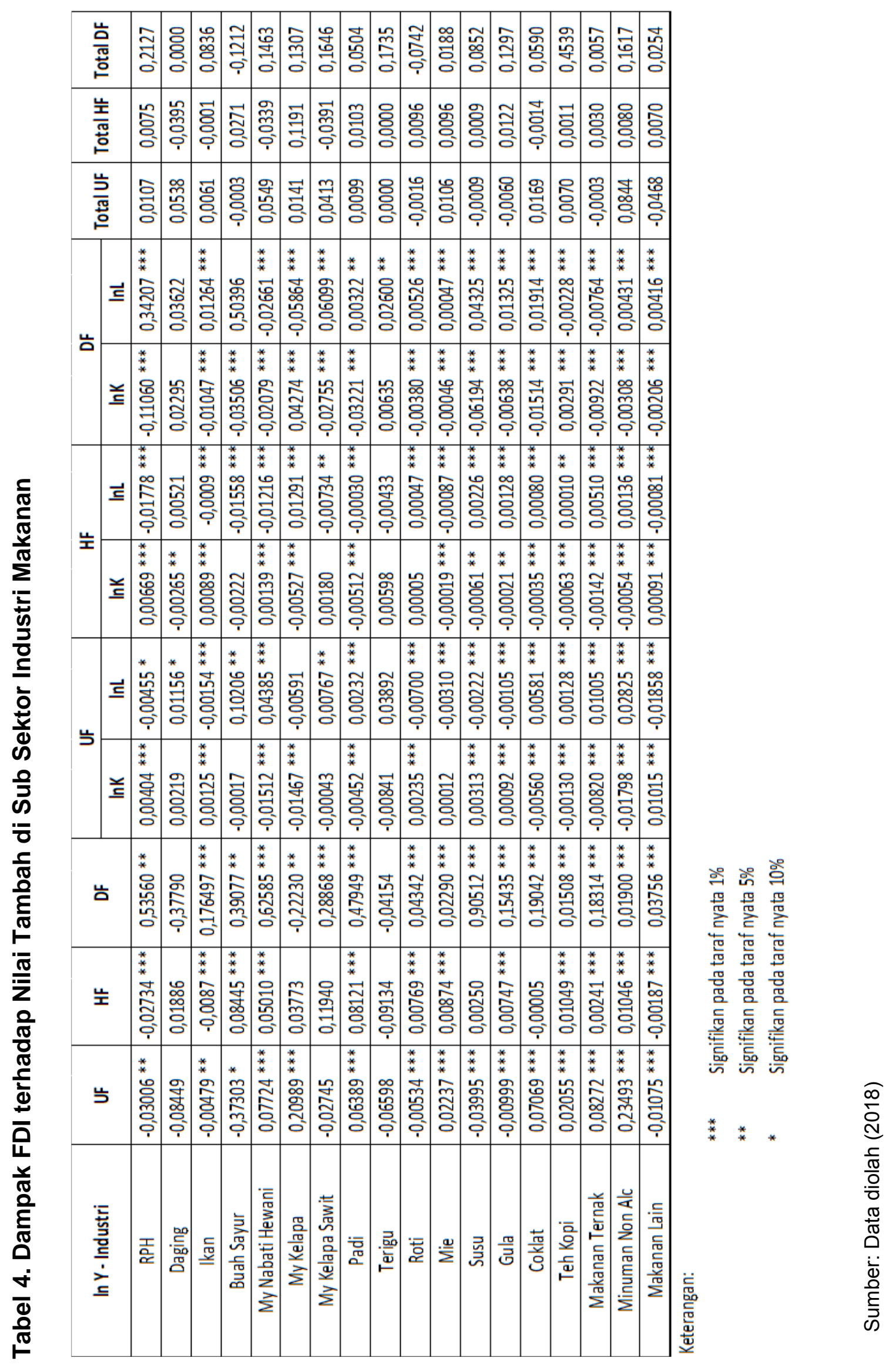


Peningkatan FDI di industri penggilingan serealia lainnya dan tepung terigu sebesar $1 \%$ akan meningkatkan perusahaan domestik mie dan makaroni sebesar 0,0106\%. Peningkatan FDI di sub sektor perkebunan coklat sebesar $1 \%$ akan meningkatkan nilai tambah perusahaan domestik makanan dari coklat sebesar 0,0169\%. Peningkatan FDI di sub sektor perkebunan kopi dan teh sebesar 1\% akan meningkatkan nilai tambah perusahaan domestik pengolahan kopi dan teh sebesar $0,007 \%$. Peningkatan FDI di sub sektor industri gula sebesar $1 \%$ akan meningkatkan nilai tambah perusahaan domestik minuman non alkohol sebesar 0,0844\%.

Berdasarkan Tabel 4 juga dapat diketahui bahwa FDI vertikal dengan keterkaitan ke belakang lebih banyak berdampak positif terhadap nilai tambah perusahaan domestik di industri makanan. Hal tersebut sesuai dengan Kokko \& Thang (2014) yang menyatakan bahwa FDI vertikal dengan keterkaitan ke belakang berdampak positif terhadap kemampuan perusahaan domestik untuk bertahan. Selain itu, hasil penelitian Javorcik (2004) juga menunjukkan bahwa FDI dengan keterkaitan ke belakang antara perusahaan asing dengan perusahaan domestik sebagai penyedia input memberikan dampak positif.

Peningkatan FDI di sub sektor industri pengolahan dan pengawetan daging sebesar $1 \%$ akan meningkatkan nilai tambah perusahaan domestik pemotongan hewan sebesar $0,2127 \%$. Peningkatan FDI di industri makanan lainnya sebesar 1\% akan meningkatkan nilai tambah perusahaan domestik pengolahan dan pengawetan ikan sebesar $0,0836 \%$, minyak nabati dan hewani sebesar 0,1463\%, minyak kelapa sebesar 0,1307\%, minyak kelapa sawit sebesar 0,1646\%, penggilingan padi, penyosohan beras, dan tepung beras sebesar 0,0504\%, dan makanan dari coklat sebesar 0,059\%. Peningkatan FDI di sub sektor industri mie dan makaroni serta industri roti dan kue sebesar $1 \%$ akan meningkatkan nilai tambah perusahaan domestik penggilingan serealia lainnya dan tepung terigu sebesar 0,1735\%. Peningkatan FDI di sektor penyediaan makanan sebesar $1 \%$ akan meningkatkan nilai tambah perusahaan domestik mie dan makaroni sebesar 0,0188\%, minuman non alkohol sebesar $0,1617 \%$, dan makanan lainnya sebesar 0,0254\%. Peningkatan FDI di industri makanan dari coklat sebesar $1 \%$ akan meningkatkan nilai tambah perusahaan 
domestik makanan dari susu sebesar 0,0852\%. Peningkatan FDI di industri minuman non alkohol sebesar $1 \%$ akan meningkatkan nilai tambah perusahaan domestik gula sebesar $0,1297 \%$ serta kopi dan teh sebesar 0,4539\%. Peningkatan FDI di sub sektor peternakan sebesar $1 \%$ akan meningkatkan nilai tambah perusahaan domestik makanan ternak sebesar $0,0057 \%$.

Perbedaan dampak FDI vertikal dengan keterkaitan ke depan terhadap nilai tambah perusahaan domestik diperkirakan disebabkan oleh perbedaan besarnya proporsi output yang digunakan oleh industri lain dengan keterkaitan ke depan dan ke belakang. Hal tersebut berdasarkan Girma et al. (2014) yang menyatakan bahwa dampak FDI tergantung dari besarnya proporsi output yang digunakan oleh industri lain dengan keterkaitan ke depan dan ke belakang dalam cluster.

Berdasarkan Tabel 4, dapat diketahui bahwa FDI horizontal juga lebih banyak berdampak positif terhadap nilai tambah perusahaan domestiknya. Hal tersebut sesuai dengan hasil penelitian Sjoholm (2016) yang menyatakan bahwa perusahaan asing memberikan dampak positif terhadap nilai tambah perusahaan domestik. Selain itu, Sari (2016) juga menyatakan bahwa FDI horizontal berdampak positif terhadap produktivitas dan efisiensi perusahaan.

Peningkatan FDI di industri pemotongan hewan sebesar $1 \%$ akan meningkatkan nilai tambah perusahaan domestiknya sebesar 0,0075\%. Peningkatan FDI di industri pengolahan dan pengawetan buah dan sayur sebesar $1 \%$ akan meningkatkan nilai tambah perusahaan domestiknya sebesar 0,0271\%. Peningkatan FDI di industri minyak kelapa sebesar $1 \%$ akan meningkatkan nilai tambah perusahaan domestiknya sebesar $0,1191 \%$. Peningkatan FDI di industri penggilingan padi, penyosohan beras, dan tepung beras sebesar $1 \%$ akan meningkatkan nilai tambah perusahaan domestiknya sebesar 0,0103\%. Peningkatan FDI di industri roti dan kue sebesar $1 \%$ akan meningkatkan nilai tambah perusahaan domestiknya sebesar 0,0096\%. Peningkatan FDI di industri makaroni dan mie sebesar $1 \%$ akan meningkatkan nilai tambah perusahaan domestiknya sebesar 0,0096\%. Peningkatan FDI di industri makanan dari susu sebesar $1 \%$ akan meningkatkan nilai tambah perusahaan domestiknya sebesar $\quad 0,009 \%$. 
Peningkatan FDI di industri gula sebesar $1 \%$ akan meningkatkan nilai tambah perusahaan domestiknya sebesar 0,0122\%. Peningkatan FDI di industri pengolahan kopi dan teh sebesar $1 \%$ akan meningkatkan nilai tambah perusahaan domestiknya sebesar 0,0011\%. Peningkatan FDI di industri makanan ternak sebesar $1 \%$ akan meningkatkan nilai tambah perusahaan domestiknya sebesar 0,003\%. Peningkatan FDI di industri minuman tidak beralkohol sebesar $1 \%$ akan meningkatkan nilai tambah perusahaan domestiknya sebesar
0,008\%. Peningkatan FDI di industri makanan lainnya sebesar $1 \%$ akan meningkatkan nilai tambah perusahaan domestiknya sebesar 0,007\%.

Berdasarkan Tabel 4 tersebut, kami mengelompokkan perusahaan domestik di sub sektor industri makanan yang mendapatkan dampak positif dari adanya FDI (baik FDI horizontal maupun vertikal dengan keterkaitan ke depan dan ke belakang) serta interaksi FDI dengan kapasitas penyerapannya (modal dan tenaga kerja). Hasil pengelompokkan tersebut dapat dilihat pada Gambar 3.

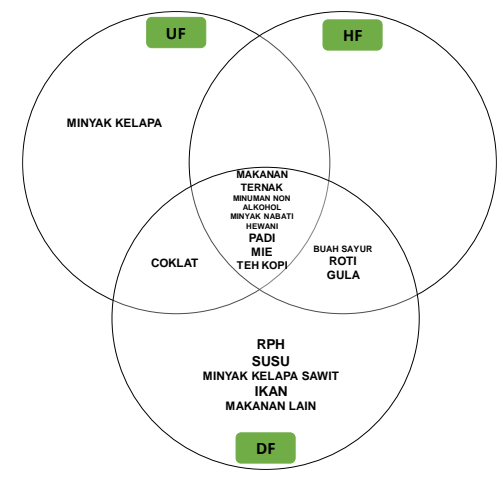

(a)

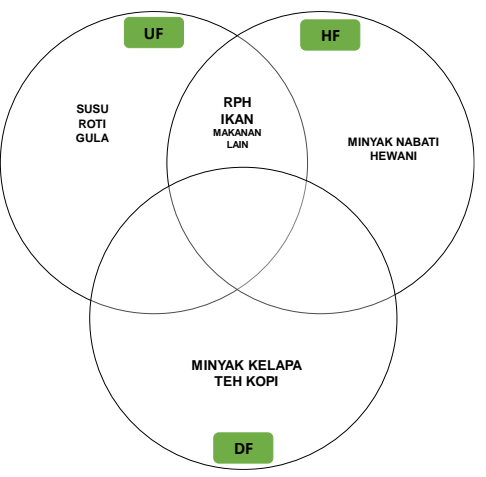

(b)

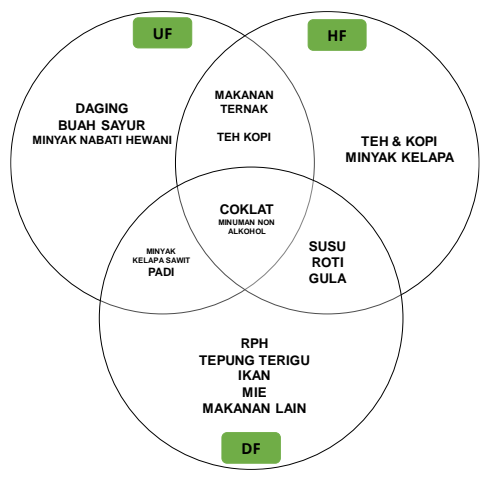

(c)

Gambar 3. Sub Sektor Industri Makanan dimana FDI dan Interaksinya dengan Modal dan Tenaga Kerja Berdampak Positif terhadap Nilai Tambah

Keterangan:

(a) Sub sektor industri dimana FDI berdampak positif terhadap nilai tambah

(b) Sub sektor industri dimana interaksi antara FDI dengan modal berdampak positif terhadap nilai tambah

(c) Sub sektor industri dimana interaksi antara FDI dengan tenaga kerja berdampak positif terhadap nilai tambah

Berdasarkan Gambar 3, dapat depan dan ke belakang lebih banyak diketahui bahwa FDI, baik horizontal memberikan dampak positif maupun vertikal dengan keterkaitan ke dibandingkan dengan dampak 
negatifnya terhadap nilai tambah di industri makanan. Hal tersebut sesuai dengan Sjoholm (2016) yang menyatakan bahwa perusahaan asing memberikan dampak positif terhadap nilai tambah perusahaan domestik. FDI yang paling banyak memberikan dampak positif terhadap nilai tambah industri domestik makanan adalah FDI yang menggunakan bahan baku dari perusahaan domestik (FDI vertikal dengan keterkaitan ke belakang). Hal tersebut disebabkan karena pada umumnya, kontrak antara pemasok input domestik dengan perusahaan asing memaksakan pemasok input dengan persyaratan kualitas produk dan manajemen atau teknologi yang lebih tinggi. Perusahaan asing akan melakukan alih teknologi langsung ke pemasok domestik sehingga pemasok domestik mendapatkan keuntungan berupa peningkatan nilai tambah (Javorcik, 2004).

Beberapa sub sektor industri makanan domestik yang memperoleh bahan baku dari perusahaan asing perlu meningkatkan modalnya untuk mendapatkan nilai tambah yang lebih tinggi dari FDI. Beberapa sub sektor tersebut adalah industri pemotongan hewan, industri pengolahan dan pengawetan ikan, industri makanan dari susu, industri makaroni dan mie, industri roti dan kue, serta industri gula. Perusahaan asing diperkirakan akan melakukan kerja sama sub contracting dengan perusahaan domestik yang memiliki modal besar. Hal tersebut sesuai dengan Kurita et al (2017) yang menyatakan bahwa perusahaan asing memberikan dampak positif terhadap nilai tambah perusahaan yang lebih besar. Javorcik (2004) juga menyatakan bahwa untuk mendapatkan keuntungan dari FDI dengan keterkaitan ke depan, perusahaan domestik perlu memiliki kapasitas yang memadai. Namun, beberapa sub sektor industri makanan domestik yang memperoleh bahan baku dari perusahaan asing pun mendapatkan dampak negatif berupa penurunan nilai tambah. Beberapa sub sektor tersebut adalah industri minyak kelapa, industri minyak nabati dan hewani, industri penggilingan padi, penyosohan beras, dan tepung beras, industri coklat dan kembang gula, industri pengolahan kopi dan teh, industri minuman tidak beralkohol, dan industri makanan lainnya.

Interaksi antara FDI horizontal dan vertikal dengan keterkaitan ke depan dan ke belakang dengan tenaga kerja berdampak positif terhadap nilai tambah perusahaan domestik. Hal tersebut 
menunjukkan bahwa untuk menggunakan bahan baku dari mendapatkan dampak positif dari perusahaan domestik di 12 sub sektor adanya FDI diperlukan kapasitas penyerapan berupa tenaga kerja yang mencukupi. Hal tersebut sesuai dengan Kalai \& Zghidi (2017) yang menyatakan bahwa FDI memberikan dampak eksternalitas positif melalui peningkatan tenaga kerja.

Berdasarkan Gambar 3, dapat diketahui bahwa peningkatan tenaga kerja akan lebih banyak meningkatkan dampak FDI terhadap nilai tambah industri makanan domestik. Sebagian besar dampak positif tersebut berasal dari FDI yang menggunakan bahan baku dari perusahaan domestik. Hal tersebut menunjukkan bahwa perusahaan asing melakukan kerja sama sub contracting dengan pemasok bahan baku domestik yang banyak menggunakan tenaga kerja. Hal tersebut sesuai dengan Braconier (2005) dan Markusen (1995) yang menyatakan bahwa perusahaan asing menanamkan modalnya di negara tuan rumah karena ingin mendapatkan bahan baku murah, yang didapatkan dari perusahaan domestik dengan labor intensive, dimana upah tenaga kerja murah. Dari 18 sub sektor industri makanan, peningkatan tenaga kerja akan meningkatkan dampak FDI yang industri makanan.

Peningkatan tenaga kerja juga akan lebih banyak meningkatkan dampak FDI terhadap nilai tambah perusahaan domestik yang memperoleh bahan baku dari perusahaan asing dan perusahaan domestik di industri yang sama dengan investasi asing ditanamkan. Dari 18 sub sektor industri makanan, peningkatan tenaga kerja akan meningkatkan dampak FDI terhadap nilai tambah perusahaan domestik yang memperoleh bahan baku dari perusahaan asing di 9 sub sektor dan meningkatkan dampak FDI terhadap nilai tambah perusahaan domestik di industri yang sama dengan investasi asing di 8 sub sektor. Namun, di beberapa sub sektor industri makanan domestik, peningkatan tenaga kerja akan menurunkan dampak FDI terhadap nilai tambah perusahaan domestik yang memperoleh bahan baku dari perusahaan asing dan perusahaan domestik di industri yang sama dengan investasi asing ditanamkan. Hal tersebut diduga disebabkan sub sektor industri makanan membutuhkan tenaga kerja yang berpendidikan untuk mendapatkan dampak positif dari FDI. 
Fu \& Li (2010) menyatakan bahwa untuk mendapatkan dampak positif dari FDI dibutuhkan kapasitas penyerapan berupa sumber daya manusia (tenaga kerja yang berpendidikan). Sub sektor industri makanan yang membutuhkan peningkatan tenaga kerja berpendidikan untuk memperoleh dampak positif dari spillover FDI terhadap nilai tambah diantaranya adalah industri pemotongan hewan, industri pengolahan dan pengawetan ikan, industri makaroni dan mie, serta industri makanan lainnya.

\section{KESIMPULAN DAN REKOMENDASI KEBIJAKAN}

Berdasarkan penelitian yang telah dilakukan terhadap FDI horizontal dan vertikal dengan keterkaitan ke depan dan ke belakang di 18 sub sektor di sektor industri makanan selama kurun waktu 1990-2014, didapatkan kesimpulan bahwa FDI berdampak positif terhadap nilai tambah perusahaan domestik. FDI yang memberikan dampak terbesar pada nilai tambah perusahaan domestik adalah FDI yang menggunakan bahan baku dari perusahaan domestik (FDI vertikal dengan keterkaitan ke belakang). Peningkatan modal akan menurunkan dampak FDI, sementara peningkatan tenaga kerja akan meningkatkan dampak FDI terhadap nilai tambah perusahaan domestik, terutama perusahaan domestik yang memasok bahan baku bagi perusahaan asing .

Pemerintah sebaiknya membuka investasi asing di industri yang paling hilir, seperti industri makanan lainnya, industri minuman tidak beralkohol, dll. Namun dengan persyaratan untuk menggunakan bahan baku yang berasal dari industri domestik. Pemerintah agar membuka peluang juga terhadap investasi asing di sektor pertanian (FDI vertikal dengan keterkaitan ke depan), namun dengan persyaratan agar investor asing melakukan kerja sama sub contracting dengan perusahaan domestik di sektor hilir, melakukan transfer teknologi, dan melakukan pelatihan tentang teknologi maju di industri domestik.

Pemerintah dapat membuka investasi asing di industri makanan, namun dengan persyaratan agar investor asing melakukan transfer teknologi serta memperkenalkan dan memberikan pelatihan tentang teknologi maju di industri makanan domestik. Pemerintah dapat membuka investasi asing di sektor penyediaan makanan (FDI vertikal dengan keterkaitan ke belakang) dengan persyaratan untuk melakukan kerja sama sub contracting 
dengan perusahaan makanan domestik. Namun, karena sektor penyediaan makanan tidak memberikan dampak FDI yang besar, maka perlu dibatasi dengan maksimal kepemilikan saham.

Agar perusahaan domestic dapat memperoleh dampak positif dari FDI horizontal, pemerintah perlu memperkuat industri domestik dengan memberikan fasilitasi pembiayaan dalam rangka penguatan modal dan memberikan pelatihan tentang teknologi maju dalam rangka peningkatan capacity building. Perusahaan domestik pun harus meningkatkan kualitas tenaga kerjanya (capacity building).

\section{UCAPAN TERIMA KASIH}

Kami sampaikan terima kasih kepada semua pihak yang telah membantu kami dalam proses penyusunan naskah jurnal hingga terbitnya jurnal ini.

\section{DAFTAR PUSTAKA}

Badan Koordinasi Penanaman Modal. (2017). Perkembangan Investasi Berdasarkan Kriteria Baku Lapangan Industri [internet]. [Diakses pada 2017 November 11]. Tersedia pada http://www.bkpm.go.id.

Badan Pusat Statistik. (2018). Statistik Indonesia. BPS, Jakarta.

Beugelsidjk, S., Roger, S \& Remco Z. (2008). The Impact of Horizontal and Vertical FDI on Host's Country Economic Growth. International Business Review 17 (2008) 452-472. Elsevier Ltd.
Braconier, H., Pehr-Johan Norback \& Dieter Urban. (2005). Reconciling the Evidence on the Knowledge-Capital Model. Review of International $\begin{array}{llll}\text { Economics } 13 & \text { (4), 770-786 }\end{array}$ (September).

Buckley, PJ \& Mark, C. (1981). The Optimal Timing of Foreign Direct Investment. The Economic Journal Vol 91, No. 361 (Mar., 1981) pp. 75-87. Wiley.

Crespo, N \& Fontoura, MP. (2007). Determinant Factors of FDI Spillovers - What Do We Really Know? World Development Vol. 35, No. 3, pp. 410425, 2007. Elsevier Ltd.

Fatkhurahman. (2017). Peran Modal Manusia dan Modal Investasi terhadap Nilai Produksi Industri Kecil di Kota Pekanbaru. Jurnal Benefita 2(1) Februari 2017 (1-9).

Fu Miao \& Li Tieli. (2010). Human Capital as a Determinant of FDI Technology Spillovers and It's Threshold Effects in China: An Analysis Based on Multiple Productivity Estimates. Working Paper 21/2009. United Nations Industrial Development Organization. Vienna, 2010.

Girma, S., Gong, Y., Gorg, H \& Lancheros, S. (2014). Estimating Direct and Indirect Effects of Foreign Direct Investment on Firm Productivity in The Presence of Interaction Between Firms. Journal of International Economics. Elsevier Inc.

Javorcik, BS. (2004). Does Foreign Direct Investment Increase The Productivity of Domestic Firms? In Search Spillovers Through Backward Linkages. The American Economic Review Vol. 94, No. 3, June 2004.

Kalai, M \& Zghidi, N. (2017). Foreign Direct Investment, Trade, and Economic Growth in MENA Countries: Empirical Analysis Using ARDL Bound Testing Approach. Springer. Journal of the Knowledge Economy, Vol 10 Issue 1, PP $397-421$. 
Kee, HL. (2014). Local Intermediate Inputs and The Shared Supplier Spillovers of Foreign Direct Investment. Journal of Development Economics 112 (2015) 56-71. Elsevier Inc.

Kokko, A \& Thang, TT. (2014). Foreign Direc.t Investment and The Survival of Domestic Private Firms in Vietnam. Asian Development Review, Vol. 31, No.1, pp. 53-91. Asian Development Bank and Asian Development Bank Institute.

Krugman, PR. (1994). International Economics: Theory and Practice. New York: Harper Collins.

Kurita, K., Monzen, M \& Rofik, K. (2017). FDI Spillover Effects on Productivity Varying from the Size of Firm and Industries in Indonesia. International Journal of Small and Medium Enterprises and Business Sustainabilty, Vol.2, No.3 (July 2017), pp.51-59. Center for Industry, SME and Business Competition Studies, USAKTI.

Liang, FH. (2016). Does Foreign Direct Investment Improve The Productivity of Domestic Firms? Technology Spillovers, Industry Linkages, and Firm Capabilities. Research Policy xxx (2016) Xxx-xxx. Elsevier Inc.

Liu, Z. (2008). Foreign Direct Investment and Technology Spillovers: Theory and Evidence. Journal of Development Economics 85 (2008) 176-193. Elsevier Inc.

Maharani, CND. (2013). Analisis Nilai Tambah dan Kelayakan Usaha Pengolahan Limbah Padat Ubi Kayu (Onggok) di Kecamatan Pekalongan, Kabupaten Lampung Timur. Skripsi. Sosial Ekonomi Pertanian, Fakultas
Pertanian, Universitas Lampung. Bandar Lampung.

Markusen, JR. (1995). The Boundaries of The Multinational Enterprise and Theory of International Trade. The Journal of Economic Perspectives Vol. 9, No. 2, (Spring, 1995), pp. 169189. American Economic Association.

Morrison, CJ. (1997). Structural Change, Capital Investment and Productivity in the Food Processing Industry. American Journal of Agricultural Economics, 70(1), 110-125.

Romer, D. (2006). Advanced Macroeconomics, $\quad 3^{\text {rd }}$ edition. McGraw-Hill Irwin, New York.

Sari, DW., Khalifah, NA \& Suyanto, S. (2016). The Spillover Effects of Foreign Direct Investment on The Firms Productivity Performance. Springer. Journal of Productivity Analysis, Vol. 46 Issue 2-3, PP 397 421.

Sjoholm, F. (1998). Productivity Growth in Indonesia: The Role of Regional Characteristics and Direct Foreign Investment. Working Paper in Economics and Finance No. 216 January 1998. Stocholm School of Economics, Sweden.

Sjoholm, F. (2016). Foreign Direct Investment and Value Added in Indonesia. Working Paper 2016:31. Department of Economics, School of Economics and Management, Lund University.

Slamet, UU. (2005). Nilai Tambah dan Balas Jasa Faktor Produksi Pengolahan Hasil-Hasil Pertanian. Buletin Pendidikan No.08 Tahun 2005. Universitas Mercu Buana, Jakarta. 
